\title{
PENGARUH PENGAWASAN INTERNAL TERHADAP IMPLEMENTASI SISTEM AKUNTANSI KEUANGAN DAERAH DAN KINERJA STEWARDSHIPS DI KABUPATEN MUARO JAMBI
}

\author{
oleh : \\ *) Asrini, S.E., M.SA. \\ **) Dosen Tetap STIE Muhammadiyah Jambi \\ e-mail: asrini.msa@gmail.com
}

\begin{abstract}
Abstrak
Penelitian ini dilakukan atas dasar hasil Laporan Keuangan Pemerintah Daerah sehingga laporan keuangan Pemerintah Muaro Jambi belum memenuhi kriteria sebagai persyaratan kualitas laporan keuangan. Fokus penelitian untuk menjelaskan pengendalian internal, pelaksanaan sistem akuntansi keuangan lokal dan kinerja penata layanan sebagai pemkab Muaro Jambi. Keterkaitan antara pengendalian internal dengan pelaksanaan sistem akuntansi keuangan lokal Kabupaten Muaro Jambi, oleh sebagian dan sekaligus pengendalian internal dan pelaksanaan sistem akuntansi keuangan lokal terhadap kinerja penata layanan yang dilakukan di Kabupaten Muaro Jambi. Metode penelitian menggunakan explanatory research dengan pendekatan survei. Analisis yang digunakan adalah analisis jalur dengan skala interval pengukuran. Uji hipotesis dilakukan dengan menggunakan uji $t$ dan secara simultan menggunakan uji $F$ dengan taraf signifikansi $(\alpha)$ sebesar 0,05. Hasil penelitian menunjukkan bahwa pengendalian internal pertama, pelaksanaan sistem akuntansi keuangan lokal, kinerja stewardships sangat baik; Kedua, ada korelasi antara pengendalian internal dengan pelaksanaan sistem akuntansi keuangan daerah; Dengan demikian, pengendalian internal sebagian berpengaruh terhadap kinerja sistem akuntansi keuangan secara signifikan berpengaruh secara signifikan terhadap kinerja penatagunaan dan secara simultan pengendalian internal dan pelaksanaan sistem akuntansi keuangan lokal berpengaruh secara langsung dan tidak langsung terhadap signifikansi.
\end{abstract}

Kata kunci: pengendalian internal, pelaksanaan sistem akuntansi keuangan lokal, kinerja stewardship

\section{LATAR BELAKANG PENELITIAN}

Penerapan akuntabilitas publik oleh pemerintah pusat dan daerah bertujuan untuk mengeliminir penyimpangan-penyimpangan dalam penegelolaan keuangan publik, dan mendorong pelaksana tugas menyajikan data-data laporan keuangan yang sesuai dengan peraturan serta memenuhi sistem Standar Akuntansi Pemerintah (SAP), (Halim, 2004 : 61). Penerapan atas sistem akuntamsi keungan daerah akan berdampak pada pengelolaan keuangan daerah terkait dengan alokasi anggaran publik tersebut memiliki akan berperan penting pada kinerja stewardships, kinerja manajer dan organisasi dalam kepemerintahan (Tausikal, 2009: 26; Hay,1997) dengan tingkat akurasi dan akuntabilitas manajemen keuangan daerah sangat tergantung dari peran pengawasan internal pada APBD yang 
diperuntukan untuk kepentingan masyarakat umum. Sesuai dengan pendapat Suwardjono (2005: 14) bahwa peran nyata akuntansi bagi kehidupan sosial ekonomi jika informasi yang dihasilkan oleh akuntansi dapat mengendalikan perilaku pengambil kebijakan ekonomi untuk bertindak menuju ke suatu pencapaian tujuan sosial dan ekonomi negara.

Secara spesifik Alamsyah, (1997:79) mengatakan bahwa pengawasan terhadap APBD untuk menjamin bahwa: (1) alokasi anggaran sesuai dengan prioritas daerah dan diajukan untuk kesejahteraan masyarakat, (2) menjaga agar penggunaan APBD ekonomis, efisien dan efektif dan (3) menjaga agar Implementasi APBD benar-benar dapat dipertanggungjawabkan dengan pengelolaan keuangan daerah yang transparan dan akuntabilitas dalam mengeliminir terjadinya kebocoran.

Sedangkan Hay, (1997) menjabarkan bahwa secara umum tujuan akuntansi dan pelaporan keuangan bagi pemerintah untuk di gunakan sebagai sarana informasi yang: (1) menyajikan informasi keuangan yang berguna untuk pengambilan keputusan ekonomi, politik, dan sosial serta penampilan akuntabilitas dan stewardships; (2) menyajikan informasi yang berguna untuk mengevaluasi kinerja manajer dan organisasi dalam kepemerintahan (Tausikal, 2009: 26).

Tidak di pungkiri bahwa masih ada laporan keuangan pemerintah daerah memiliki kelemahan dalam menyajikan data-data yang sesuai dengan peraturan, dan ada kemungkinan terjadi penyimpangan-penyimpangan dalam mengimplementasikan anggaran publik. Hasil pemeriksaan di tinjau dari Sistem Pengendalian Intern, mengungkapkan bahwa masih ditemukan kelemahan pada Implementasi APBD yaitu sistem dan prosedur akuntansi belum diterapkan pada bagian Keuangan dan masing-masing SKPD. (www.bpk.go.id). Dalam penelitian Anita Wulandari,(2001) kemampuan pengelolaan keuangan Pemda Kota masih dihadapkan pada kendala rendahnya kemampuan keuangan daerah, yang dilihat dari rendahnya kontribusi Pendapatan Asli Daerah.Padahal, lapoaran keuangan atau Laporan Keuangan Pemerintah Daerah (LKPD) sangat penting bagi masyarakat, parawakil rakyat, lembaga pengawas, lembaga pemeriksa, pihak donasi, pers, investor, kreditor dan pihak-pihak lain yang berkepentingan sebagai dasar untuk perencanaan, pengendalian, dan pengambilan keputusan. (Mahmudi, $2010: 2$ ).

Berdasarkan uraian di atas, maka penulis mencoba mengemukakan hipotesis sebagai berikut:

1) Apakah Terdapat Hubungan Antara Pengawasan Internal Dan Implementasi Implementasi Sistem Akuntansi Keuangan Daerah Terhadap Kinerja Stewardships? 
2) Apakah Pengawasan Internal berpengaruh pada Implementasi Sistem Akuntansi Keuangan Daerah?

3) Apakah Implementasi Implementasi Akuntansi Keuangan Daerah Berpengaruh Terhadap Kinerja Stewardships?

4) Apakah Pengawasan Internal Berpengaruh Terhadap Kinerja Stewardships?

Tujuan penelitian yang dilakukan dalam penelitian ini adalah untuk memberikan bukti empiris tentang:

1) Pengaruh Pengawasan Internal Terhadap Implementasi Implementasi Sistem Akuntansi Keuangan Daerah Dan Kinerja Stewardships.

2) Pengaruh Implementasi Sistem Akuntansi Keuangan Daerah Terhadap Kinerja Stewardships

3) Pengawasan Intern Dan Implementasi Sistem Akuntansi Keuangan Daerah Secara Simultan Berpengaruh Terhadap Kinerja Stewardships.

\section{TINJAUAN PUSTAKA}

\subsection{Pengawasan Internal}

Pemahaman terhadap Pengawasan internal dalah suatu upaya yang sistematik untuk menetapkan kinerja standar pada perencanaan untuk merancang sistem umpan balik informasi, untuk membandingkan kinerja aktual dengan standar yang telah ditentukan, untuk menetapkan apakah telah terjadi suatu penyimpangan tersebut, serta untuk mengambil tindakan perbaikan yang diperlukan untuk menjamin bahwa semua sumber daya perusahaan atau pemerintahan telah digunakan seefektif dan seefisien mungkin guna mencapai tujuan perusahaan atau pemerintahan (Winidyaningrum dan Rahmawati, 2010).

Menurut Arifin Sabeni dan Imam Gozali (1997:67) tentang pengawasan Internal adalah suatu alat pengawasan dari pimpinan organisasi yang bersangkutan untuk mengawasi apakah kegiatan-kegiatan bawahannya telah sesuai dengan rencana dan kebijakan yang telah ditentukan. Dengan demikian secara hakikat bahwa Pengawasan berfungsi untuk pencegahan sedini mungkin akan terjadinya penyimpanganpemyimpangan dalam perencanaan, mengakolaksikan, melaksanakan dan mengevaluasi sumberdaya publik. Sehingga kemungkinan kecil terjadi pemborosan, penyelewenangan, 
hambatan, kesalahan dan kegagalan dalam mencapai tujuan dan Implementasi tugastugas organisasi kepemerintahan.

Fungsi pengawasan intenal atas penyelenggaraan pemerintahan diperlukan untuk menjamin agar Implementasi kegiatan pemerintahan berjalan sesuai dengan rencana dan sesuai dengan ketentuan peraturan perundang-undangan yang berlaku, mewujudkan good governance, clean government, dan mendukung penyelenggaraan pemerintahan yang efektif dan efisien, transparan, akuntabel, serta bersih dan bebas dari praktik-praktik korupsi, kolusi maupun nepotisme. Maka pengawasan pada penyelenggaran pemerintahan melalui pengawasan melekat, pengawasan masyarakat, dan pengawasan fungsional (Winidyaningrum dan Rahmawati, 2010).

Pemahaman tentang pengawasan fungsional adalah pengawasan yang dilakukan oleh lembaga/aparat pengawasan yang dibentuk atau ditunjuk khusus untuk melaksanakan fungsi pengawasan secara independen terhadap obyek yang diawasi. Pengawasan fungsional dilakukan oleh lembaga/badan/unit yang mempunyai tugas dan fungsi melakukan pengawasan fungsional melalui audit, investigasi, dan penilaian untuk menjamin agar penyelenggaraan pemerintahan sesuai dengan rencana dan ketentuan perundang-undangan yang berlaku. Pengawasan fungsional bisa dilakukan dari ekstern pemerintah maupun pengawas intern pemerintah. Pengawasan ekstern pemerintah dilakukan oleh Badan Pemeriksa Keuangan (BPK), sedangkan pengawasan intern pemerintah dilakukan oleh Aparat Pengawasan Intern Pemerintah (APIP) sesuai ketentuan peraturan perundang-undangan yang berlaku (Susmanto, 2008).

Salah satu pengawasan internal perlu di lakukan pada APBD. Hal tersebut di ungkapkan oleh Mardiasmo,(2002:38) pengawasan terhadap APBD penting dilakukan untuk menjaga dan memastikan bahwa alokasi anggaran sesuai dengan prioritas daerah dan diajukan untuk kesejahteraan masyarakat, menjaga agar penggunaan APBD ekonomis, efisien dan efektif dan menjaga agar Implementasi APBD benar-benar dapat dipertanggungjawabkan atau dengan kata lain bahwa anggaran telah dikelola secara transparan dan akuntabel untuk meminimalkan terjadinya kebocoran pada setiap tahap bukan hanya pada tahap evaluasi saja (Alamsyah, 1997:79).

Dalam penelitian ini fokus pada fungsi pengawasan internal yaitu suatu fungsi penilaian yang independen dalam suatu organisasi untuk menguji dan mengevaluasi kegiatan organisasi yang dilakukan berkaitan dengan keuangan daerah. 


\subsection{Sistem Akuntansi Keuangan}

Menurut Eko Hariyanto (2007:10) Sistem Akuntansi Keuangan Daerah yaitu Serangkaian secara sistematik (siklus akuntansi) dari prosedur, penyelenggara, peralatan, dan elemen lain untuk mewujudkan fungsi akuntansi sejak analisis transaksi sampai dengan pelaporan keuangan di lingkungan organisasi pemerintah. Aturan dasar sistem akuntansi keuangan sebagai berikut : Identifikasi, Pengklasifikasian, Adanya sistem pengendalian untuk menjamin reliabilitas, Menghitung pengaruh masing-masing operasi. Pencatatan dan pelaporan diperlukan untuk memenuhi 3 kebutuhan yaitu: legal, managerial dan stewardships (Mardiasmo,2002: 147-148).

Secara ekspilisit bahwa Sistem Akuntansi Pemerintah Daerah merupakan sistem terpadu yang menggabungkan prosedur manual dan proses computerisasi dalam pengambilan data, pembukuan dan pelaporan semua transaksi keuangan, aset, utang dan ekuitas seluruh entitas pemerintah daerah yang sistematik dan penyajian laporan keuangan yang handal untuk kepentingan perencanaan dan pengendalian program publik.

\subsection{Implementasi Sistem Akuntansi Pemerintah Daerah}

Definisi implementasi sistem akuntasi keuangan pemerintah daerah dalam Mardiasmo, (2002: 12) menjelaskan bahwa implementasi sistem akuntansi pemerintahan merupakan suatu kondisi yang menunjukkan kemudahan dan kemanfaatan sistem akuntansi pemerintahan sebagai pedoman pokok dalam penyusunan dan penyajian laporan keuangan pemerintah.

Fungsi dalam implemntasi sistem akuntansi keuangan pemerintah daerah sangat diperlukan untuk menjamin konsistensi dalam pelaporan keuangan dan dapat dijadikan pedoman dalam menyajikan informasi yang diperlukan berbagai pihak untuk berbagai kepentingan (general purposes financial statements), karena sistem akuntansi memberikan landasan tentang prosedur, teknik, dan metode yang layak untuk merekam segala peristiwa penting kegiatan pemerintah. Sehingga implementasi sistem akuntansi pemerintahan tersebut dapat menjamin kegiatan pemerintah terekam dengan baik dengan ukuran-ukuran yang jelas dan akuntable dengan melalui proses akuntansi dalam bentuk laporan dari semua transaksi pemerintah, dan untuk menjamin konsistensi dalam pelaporan keuangan (Hendriksen, 2005:79). 
Implementasi pengelolaan keuangan daerah merupakan suatu aktivitas yang mencakup: tahap perencanaan, tahap Implementasi Anggaran Pendapatan Belanja Daerah (APBD) termasuk didalamnya bagaimana penatausahaannya, tahap pertanggungjawaban dan pengawasa, dari implementasi pengelolaan terdiri: planning and budget setting keuangan daerah yang efektif (Abdul Rohman, 2009).

\subsection{Pemahaman Teori stewardships}

Sebagai penggerak proses transaksi publik sistem akuntansi untuk mengatasi komplesitas dan spesialisasi perkembangan pengolahan keuangan sektor publik, yang mengakibatkan principal semakin sulit untuk melaksanakan sendiri fungsi-fungsi pengelolaan. Akuntansi organisasi sektor publik untuk memenuhi kebutuhan informasi bagi hubungan antara stewards dengan principals. Berbagai keterbatasan, pemilik sumber daya (capital suppliers/principals) mempercayakan pengelolaan sumber daya tersebut kepada pihak lain (steward = manajemen) yang lebih capable dan siap.

Teori stewardships dapat diterapkan pada penelitian akuntansi organisasi sektor publik seperti organisasi pemerintahan dan non profit lainnya (Latifah, Lyna dan Arifin Sabeni. 2007). Beberapa pertimbangan penggunaan stewardships theory dalam penelitian ini, sebagai pandangan bahwa manajemen sebagai stewards (pelayan/penerima amanah/pengelolah). Stewardships theory memandang bahwa manajemen organisasi sebagai “stewards/penatalayanan”, akan bertindak dengan penuh kesadaran, arif dan bijaksana bagi kepentingan organisasi.

Selain itu teori Stewardships mengacu atas asumsi filosofis mengenai sifat manusia yakni manusia pada hakekatnya dapat dipercaya, mampu bertindak dengan penuh tangung jawab, memiliki integritas dan kejujuran terhadap pihak lain. Eksistensi Pemerintah Daerah sebagai suatu lembaga yang dapat dipercaya untuk bertindak sesuai dengan kepentingan publik dengan melaksanakan tugas dan fungsinya dengan tepat, dan efisien, akuntable, serta dapat dipertanggungjawabkan.Dalam melaksanakan tanggungjawab tersebut maka stewards (manajemen dan auditor internal) menggunakan semua kemampuan dan keahliannya untuk mengefektifkan pengendalian internal sehingga menghasilkan laporan informasi keuangan yang berkualitas. 


\subsection{Tinjauan Penelitian Terdahulu}

Sebagai rujukan dalam pengembangan model konseptual penelitian ini, ada beberapa hasil penelitian terdahulu yang digunakan antara lain:

Anita Wulandari,(2001) fokus penelitia tentang Kemampuan Keuangan Daerah Kota Jambi dalam Implementasi Otonomi Daerah. Hasil empiris ini menunjukkan bahwa dalam Implementasi otonomi daerah, Kota Jambi dihadapkan pada kendala rendahnya kemampuan keuangan daerah, yang dilihat dari rendahnya kontribusi Pendapatan Asli Daerah.

Hasil empiris Abdul Rohman (2009), tentang Pengaruh Implementasi Sistem Akuntansi, Pengelolaan Keuangan Daerah terhadap Fungsi Pengawasan intern dan Kinerja Pemerintah Daerah (Survei pada Pemda di Jawa Tengah). Dengan menggunakan analisis jalur (path analysis), menunjukkan bahwa implementasi sistem akuntansi dan pengelolaan keuangan daerah dapat mempengaruhi dan memperlancar Implementasi fungsi pengawasan intern pada Pemerintah daerah di Jawa Tengah. Selain itu implementasi sistem akuntansi pemerintahan, implementasi pengelolaan keuangan daerah, dan fungsi pengawasan intern berpengaruh terhadap kinerja Pemerintah daerah.

\section{PENGEMBANGAN HIPOTESIS}

Penelitian ini bertujuan untuk menjelaskan bagaimana hubungan antara pengawasan internal dan implementasi sistem keuangan daerah terhadap kinerja stewardshipss, maka model kerangka konseptual penelitian ini diilustrasikan pada gambar 3.1 di bawah ini:

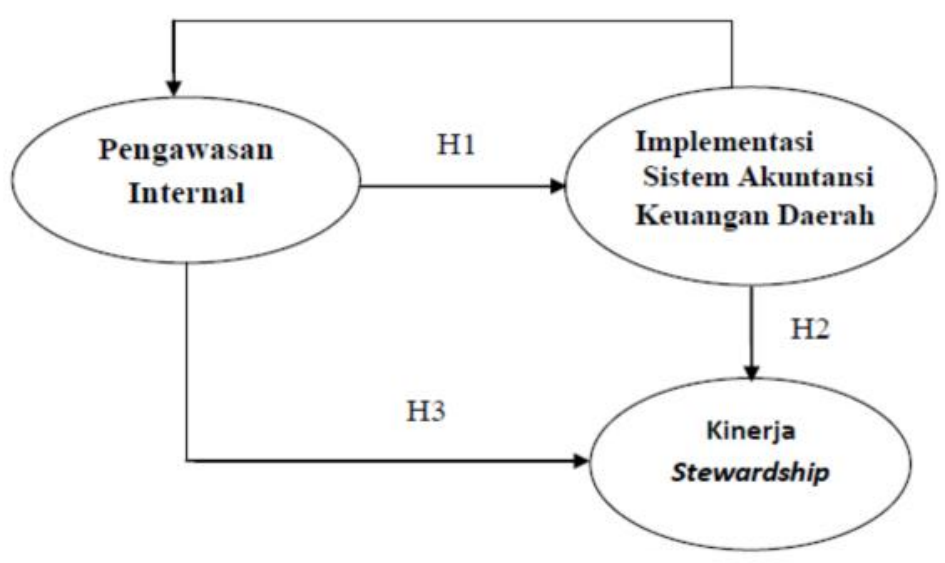

Gambar 1. Kerangka Konseptual 


\section{METODE PENELITIAN}

\subsection{Jenis Penelitian}

Penelitian ini merupakan penelitian survey. Penelitian ini merupakan field research, karena dilakukan dalam lingkungan alami yang sesungguhnya. Dengan demikian, penelitian ini menggambarkan hubungan kausal antara sistem pengelolaan keuangan daerah dan implementasi sistem akuntansi keuangan daerah terhadap kinerja stewardships di Kabupaten Muaro Jambi Kota Jambi.

\subsection{Populasi dan Sampel}

Populasi penelitian ini adalah seluruh Pegawai Dinas Pendapatan Pengelolaan Keuangan Daerah dan Aset Daerah (DPPKAD) Kabupaten Kabupaten Muaro Jambi Kota Jambi. Sampel dalam penelitian ini adalah Pegawai Dinas Pendapatan Pengelolaan Keuangan Daerah dan Aset Daerah (DPPKAD) yang berkaitan langsung dengan aktivitas pengelolaan keuangannya dan aset daerah.

\subsection{Jenis dan Sumber Data}

Jenis data dalam penelitian ini adalah primer. Data primer adalah data yang diperoleh secara langsung dari individu, kelompok-kelompok tertentu, dan juga responden yang telah ditentukan secara spesifik oleh peneliti yang memilik data spesifik dari waktu ke waktu (Sugiyono, 2006:29). Penelitian ini dilakukan dengan cara survei, dan pengumpulan data primer dengan kuestioner yang dibuat secara berstruktur yang mana responden dibatasi dalam memberikan jawaban pada alternatif jawaban tertentu saja. Penyebaran kuestioner terhadap responden dilakukan setelah terlebih dahulu mendapat rekomendasi dari Dinas Pendapatan Pengelolaan Keuangan dan Aset Daerah (DPPKAD) Kabupaten Muaro Jambi dan pengambilan kembali kuesioner disesuaikan dengan waktu yang telah disepakati dengan DPPKAD Kabupaten Muaro Jambi.

\subsection{Definisi Operasional dan Pengukurannya}

Dalam penelitian ini terdapat dua variabel yaitu variabel dependen dan variabel independen.

1. Variabel dependen adalah tipe variabel yang dijelaskan atau dipengaruhi oleh variabel independen (Nur Indriantoro, dan Bambang Supomo, 2002; 63). Variabel dependen dalam penelitian ini yaitu fungsi pengawasan keuangan daerah.

2. Variabel independen adalah tipe variabel yang menjelaskan atau mempengaruhi variabel yang lain. Variabel independen dalam penelitian ini antara lain: 
a. Pengawasan Internal Pengelolaan Keuangan Daerah

Sistem pengelolaan keuangan daerah merupakan suatu aktivitas yang mencakup: tahap perencanaan, tahap penyusunan dan penetapan APBD, tahap Implementasi APBD termasuk di dalamnya bagaimana penatausahaannya, tahap pertanggungjawaban, dan pengawasan.

b. Implementasi Sistem Akuntansi Keuangan Daerah

Implementasi sistem akuntansi keuangan daerah merupakan suatu kondisi yang menunjukkan kemudahan dan kemanfaatan sistem akuntansi pemerintahan sebagai pedoman pokok dalam penyusunan dan penyajian laporan keuangan pemerintah. Kedua variabel ini diukur dengan menggunakan instrumen pengukuran dalam bentuk kuestioner (Fachruzaman. 2010), setiap item diberi skor 1 sampai 5, yaitu : skala 5 sangat setuju, skala 4 setuju, skala 3 ragu-ragu, skala 2 tidak setuju dan skala 1 sangat tidak setuju.

c. Kinerja Stewardshipss

Kinerja Pemerintah Daerah berarti bagaimana atau sejauh mana Pemerintah Daerah menyelenggarakan urusan atau tugas-tugas publik oleh PEMDA. Pemerintah Daerah bertindak sebagai stewards, sedangkan kinerja berasal dari kata performance yang artinya manner of functioning, artinya sejauh mana/bagaimana suatu organisasi ataupun individu berfungsi sesuai dengan posisi dan/atau tugasnya. Dalam kaitannya dengan lingkup kerja Pemerintah Daerah.

\section{HASIL ANALISIS DAN PEMBAHASAN}

Dari hasil penelitian menyatakan Suatu instrumen penelitian dikatakan baik jika dapat memenuhi tiga persyaratan utama yaitu: Valid, sahih, atau absah; Reliable atau andal; dan Praktis (Cooper, Schindler :2005). Agar instrumen tersebut mampu menjadi alat pengumpul data yang andal dan konsisten. Program statistik yang digunakan adalah SPSS For Windows dan Microsoft exel.

\subsection{Pengujian Instrumen}

1. Uji Validitas

Validitas menunjukkan tingkat kemampuan suatu instrumen untuk mengungkap sesuatu yang menjadi sasaran pokok pengukuran yang dilakukan dengan instrumen tersebut. Kuestioner sebagai instrumen penelitian harus bisa mengukur apa yang ingin diukur, 
sehingga harus teruji validitasnya. Analisa confirmatoy factor dilakukan dengan cara mengkorelasikan skor-skor faktor dengan skor total setelah terlebih dahulu mengetahui kekhususan tiap faktor.

2. Uji Reliabilitas

Kuestioner sebagai instrumen dalam penelitian ini berbentuk angket yang dijawab dengan "sangat tidak setuju, tidak setuju, netral, setuju, sangat setuju. Peneliti menggunakan metode internal consistency dengan teknik alpha atau sering disebut cronbach's alpha.

\subsection{Pembahasan}

Dari hasil penelitian menyatakan bahwa nilai yang diperoleh dari perhitungan terhadap tanggapan responden mengenai Pengawasan Internal pada Dinas Kab Muaro Jambi adalah sebesar 586. Hal ini menunjukkan ke dalam interval berkategori baik, yang berarti bahwa tanggapan responden mengenai Pengawasan Internal dari 13 pertanyaan mendapat respon baik sebanyak 11 pertanyaan (87,56\%), pemaknaannya bahwa pengawasan Internal yang dilakukan atasan langsung terhadap bawahan telah dilakukan dengan baik pada Dinas Kab Muaro Jambi. Hal tersebut menunjukkan Dinas Kab Muaro Jambi menuju peningkatan dalam melakukan Pengawasan Internal yang lebih baik lagi. Adapun hasil penelitian menyatakan bahwa nilai yang diperoleh dari perhitungan terhadap tanggapan responden mengenai Implementasi Sistem Akuntansi Keuangan Daerah pada Dinas Kab Muaro Jambi adalah sebesar 598, dengan tingkat respon kategori baik sebesar 90,21\%. Hal ini menunjukkan bahwa Implementasi Sistem Akuntansi Keuangan Daerah telah dilaksanakan dengan baik pada Dinas yang berada di Dinas Kab Muaro Jambi. Pemahaman bahwa Sistem Akuntansi Keuangan Daerah merupakan faktor penting dalam reformasi keuangan daerah menuju akuntabilitas dan efisiensi. Selanjutnya, hasil penelitian menyatakan bahwa tanggapan responden atas Kinerja Pemerintah Daerah bertindak sebagai stewardships yang berada di Kabupaten Muaro Jambi adalah sebesar 479, artinya 77,78\% dari item pertanyaan mampu menjelaskan Kinerja stewardships Kabupaten Muaro Jambi dan kinerja stewardships tersebut dapat dinyatakan kategori baik.

Untuk mengetahui hubungan antara Pengawasan Internal dan Implementasi Sistem Akuntansi Keuangan Daerah pada Dinas yang berada di Kab Muaro Jambi, pengujian statistik koefisien korelasi, membuktikan bahwa koefisien korelasi hubungan 
variabel Pengawasan Internal dengan Implementasi Sistem Akuntansi Keuangan Daerah adalah sebesar 0,896 atau $89,6 \%$, artinya terdapat hubungan yang sangat kuat antara variabel Pengawasan Intern dengan dengan Implementasi Sistem Akuntansi Keuangan Daerah.

Dari pengujian hipotesa menggunakan uji t. Nilai t menunjukkan pengujian variabel independen secara individu yang dilakukan untuk melihat apakah variabel independen berpengaruh secara signifikan terhadap variabel lainnya tetap atau konstan.

Uji F menunjukkan pengujian variabel-variabel independen secara keseluruhan dan serentak yang dilakukan untuk melihat apakah variabel independen mempengaruhi variabel dependen adalah signifikan atau tidak signifikan (Ghozali, 2008: 88). Uji $\mathrm{F}$ digunakan untuk mengetahui fit model. Apabila Fhitung $>$ Ftabel atau $\rho$ value $<0,05$, maka model regresi tepat (fit), artinya sistem pengelolaan keuangan daerah dan implementasi sistem akuntansi keuangan daerah berpengaruh terhadap fungsi pengawasan keuangan daerah, dan sebaliknya apabila Fhitung < Ftabel atau $\rho$ value $\geq 0,05$ maka model regresi kurang tepat atau tidak fit.

Hasil pengujian secara parsial antara Pengawasan Internal dengan Kinerja Pemerintah Daerah sebagai stewardships, di perhitungkan dengan kriteria penolakan Ho, jika $\mathrm{t}_{\text {hitung }}>\mathrm{t}_{\text {tabel }}$. Diperoleh $\mathrm{t}_{\text {hitung }}$ sebesar 5,542 kemudian $\mathrm{t}_{\text {hitung }}$ ini dibandingkan dengan $\mathrm{t}_{\text {tabel, }}$ diperoleh $\mathrm{t}_{\text {tabel }}$ 2,262, Sehingga $t_{\text {hitung }}(5,542)>t_{\text {tabel }}(2,262)$ dan diperoleh signifikansi sebesar 0,001 . Koefisien jalur tersebut memiliki makna bahwa hipotesis Ho ditolak dan hipotesis alternatif diterima. Dengan diterimanya hipotesis alternatif (Ha) menunjukkan bahwa pada tingkat keyakinan 95\% Pengawasan Intern $\left(X_{1}\right)$ berpengaruh signifikan terhadap Kinerja stewardships (Y).

Sedangkan hasil pengujian secara parsial antara Implementasi Sistem Akuntansi Keuangan Daerah dengan Kinerja stewardships. Dengan kriteria penolakan Ho, jika $\mathrm{t}_{\text {hitung }}>\mathrm{t}_{\text {tabel' }}$, diperoleh $\mathrm{t}_{\text {hitung }}$ sebesar 3,393 kemudian $\mathrm{t}_{\text {hitung }}$ ini dibandingkan dengan $\mathrm{t}_{\text {tabel }}$, diperoleh $\mathrm{t}_{\text {tabel }}$ 2,262, Sehingga $\mathrm{t}_{\text {hitung }}(3,393)>\mathrm{t}_{\text {tabel }}(2,262)$ dan diperoleh signifikansi sebesar 0,009 . Koefisien jalur tersebut memiliki makna bahwa hipotesis Ho ditolak dan hipotesis alternatif diterima. Dengan diterimanya hipotesis alternatif (Ha) menunjukkan bahwa pada tingkat keyakinan 95\% Implementasi Sistem Akuntansi Keuangan Daerah berpengaruh signifikan terhadap Kinerja Stewardshipss. 
Selanjutnya untuk menjelaskan interaksi anteseden penelitian, di gunkan Uji F menunjukkan bahwa pengujian variabel-variabel independen secara keseluruhan dan serentak bertujuan untuk melihat signifikansi atau tidak signifikannya variabel independen mempengaruhi variabel dependen (Ghozali, 2008: 88). Selain itu Uji F digunakan untuk mengetahui fit model. Apabila Fhitung $>$ Ftabel atau $\rho$ value $<0,05$, maka model regresi tepat (fit), artinya Pengawasan internal dan implementasi sistem akuntansi keuangan daerah berpengaruh terhadap kinerja Stewardshipss, dan sebaliknya apabila Fhitung < Ftabel atau $\rho$ value $\geq 0,05$ maka model regresi kurang tepat atau tidak fit.

Hasil empiris ini, menunjukkan bahwa pengaruh secara simultan dimana $\left(\rho^{2} \mathrm{yx}_{1} \mathrm{x}_{2}\right)$ yaitu sebesar 0,962 , dengan nilai signifikansi 0,000 dimana nilai $0,000<0,05$. Dengan menggunakan uji $\mathrm{F}, \mathrm{F}_{\text {hitung }}$ diperoleh 291,600 sedangkan $\mathrm{F}_{\text {tabel }} 4,96$. Hal ini berarti $\mathrm{F}_{\text {hitung }}>$ $\mathrm{F}_{\text {tabel. }}$ Dengan demikian maka kesimpulannya adalah Ho ditolak dan Ha diterima, artinya bahwa variabel Pengawasan Internal dan Implementasi Sistem Akuntansi Keuangan Daerah secara simultan berpengaruh signifikan terhadap Kinerja stewardsips di Kab Muaro Jambi.

Secara lengkap pengaruh langsung dan tidak langsung antara variabel Pengawasan Internal dan Implementasi Sistem Akuntansi Keuangan Daerah terhadap Kinerja stewardships dapat dilihat dalam tabel dibawah ini:

\begin{tabular}{|c|c|c|c|}
\hline NUMBER & DIREC EFFECT & INDIRECT EFFECT & TOTAL EFFECT \\
\hline \multirow[t]{3}{*}{1} & $\mathrm{Y} \leftarrow \mathrm{X}_{1} \rightarrow \mathrm{Y}=\left({ }^{\rho} \mathrm{Yx}_{1}\right)^{2}$ & & 0,372 \\
\hline & & $\left(\rho_{r \times 1} \cdot r_{x 1 \times 2} \cdot \rho_{r \times 2}\right)$ & 0,230 \\
\hline & Total effect $X_{1}$ & $0,372+0,230$ & 0,602 \\
\hline \multirow[t]{3}{*}{2} & $Y \leftarrow X, Y=\left(\rho_{r \times 2}\right)^{2}$ & & 0.141 \\
\hline & & $\left(\rho_{r_{x 2}} \cdot r_{x_{1 \times 2}} \cdot \rho_{r_{x 1}}\right)$ & 0.219 \\
\hline & Total effect $X_{2}$ & $0.141+0.219$ & 0,360 \\
\hline \multirow[t]{4}{*}{3} & Total effect $X_{1}$ and $X_{2} \rightarrow Y$ & $0,602+0,360$ & 0,962 \\
\hline & Factor Effect Residu & & 0,038 \\
\hline & $\varepsilon \rightarrow \mathrm{Y}=\rho_{\mathrm{Y} s}{ }^{2}$ & & \\
\hline & & & 1 \\
\hline
\end{tabular}

Dari hasil analisis berdasarkan tabel di atas menunjukan bahwa koefisien jalur untuk Pengawasan Internal terhadap Kinerja stewardships adalah sebesar 0,602, sedangkan koefisien jalur Implementasi Sistem Akuntansi Keuangan Daerah terhadap Kinerja stewardships adalah sebesar 0,360. Hal tersebut membuktikan bahwa pengaruh secara langsung variabel Pengawasan Internal terhadap Kinerja stewardships adalah sebesar 0,372 atau sebesar 37,2\%, sedangkan pengaruh tidak langsung Pengawasan Internal terhadap 
Kinerja stewardships melalui Implementasi Sistem Akuntansi Keuangan Daerah sebesar 0,219 atau 21,9\%. Kemudian Pengaruh langsung Implementasi Sistem Akuntansi Keuangan Daerah terhadap Kinerja stewardships sebesar 0,141 atau sebesar 14,1\%. Sedangkan pengaruh tidak langsung Implementasi Sistem Akuntansi Keuangan Daerah terhadap Kinerja stewardships melalui Pengawasan Internal adalah sebesar 0,219 atau 21,9\%. Total pengaruh simultan dari Pengawasan Internal, Implementasi Sistem Akuntansi Keuangan Daerah terhadap Kinerja stewardships sebesar 0,962 atau 96,2\% model penelitian mampu menjelaskan hubungan antar variabel.

Sedangkan faktor residu atau faktor lain yang mempengaruhi Kinerja stewardships yang tidak masuk dalam variabel penelitian adalah sebesar 0,038 atau sebesar 3,8\%. Pengaruh tersebut merupakan hal yang memberikan makna selain Pengawasan Internal dan Implementasi Sistem Akuntansi Keuangan Daerah masih ada variabel penting lain yang dapat menjelaskan kinerja stewardships

\section{Kesimpulan dan Saran}

\section{Kesimpulan}

Dinas Pendapatan Pengelolaan Keuangan dan Aset Daerah (DPPKAD) Kabupaten Muaro Jambi sudah melaksanakan Pengawasan Internal, dan Sistem Akuntansi Keuangan Daerah diterapkan dengan baik. Sehingga berefek secara langsung dan tidak langsung pada kinerja stewardship.

Jika di lihat dari hasil pengujian hipotesis Pengawasan Internal dan Implementasi Sistem Akuntansi Keuangan Daerah mempunyai hubungan yang sangat kuat artinya Pengawasan Internal yang dilaksanakan efektif dan akuntable. Pengawasan internal di Kabupaten Muaro Jambi telah mampu menjalankan sistem akuntansi keuangan daerah, sehingga kemungkinan kecil akan terjadi kebocoran dan ketidakefisienan anggaran publik. Sehingga sistem akuntansi keuangan daerah dapat mendukungan kinerja stewardships.

\section{Saran}

1. Bagi Dinas dan Pemerintah Kabupaten Muaro Jambi

a. Diharapkan pada Dinas Pendapatan Pengelolaan Keuangan dan Aset Daerah (DPPKAD) Kabupaten Muaro Jambi dapat melaksanakan pengawasan internal, dan implementasi 
sistem akuntansi keuangan daerah lebih baik dan berkelanjutan sesuai dengan peraturan dan prosedur yang telah di tetapkan.

b. Kedepannya diharapakan setiap dinas di kota Jambi atau khususnya Kab Muaro Jambi mengimplementasi sistem akuntansi daerah untuk mengefektifkan aktivitas, dan mencegah terjadinya penyelewengan anggaran. Karena ada jaminan bahwa seluruh kegiatan pemerintah memiliki rekam jejak dengan baik dengan ukuran-ukuran yang jelas dan akuntable dengan melalui proses akuntansi dalam bentuk laporan dari semua transaksi pemerintah, dan untuk menjamin konsistensi dalam pelaporan keuangan.

2. Bagi Peneliti Selanjutnya

Penelitian yang akan datang, lebih fokus membahas sistem akuntansi keuangan daerah, dengan mempertimbngkan variabel yang dapat menjelaskan perilaku stewardships, sumberdaya manusia, maupun Sistem Perencanaan dan Pengendalian, Anggaran Kinerja, pengaliokasi anggaran, dan variabel lain.

\section{DAFTAR PUSTAKA}

Abdul Halim. 2004. Akuntansi Keuangan Daerah. Jakarta: Salemba Empat

Alamsyah. 1997. Mekanisme Pengawasan APBD di Kabupaten Sleman, Tesis Magister Akuntansi Publi. Univ. Gadjah Mada, Jogjakarta.

Anita Wulandari. 2001. Kemampuan Keuangan Daerah. Jurnal Kebijakan dan Administrasi Publik Vol.5 No.2 November

Arifin Sabeni, dan Imam Gozali.1995. Pokok-pokok Akuntansi Pemerintahan. Edisi 4. Yogyakarta. BPFE

Cooper, Donald R., Pamela S., Schindler. 2005. Business Research Methode. 7th Edition Mc Graw- Hill International Edition, Boston.

Eko Harianto. 2005. Peranan Akuntansi Keuangan Daerah dalam Mewujudkan Good Governance. Pada Regional Accounting Seminar di Universitas Siliwangi. Tidak dipublikasikan

Fachruzaman. 2010. Implementasi Sistem Pengukuran Kinerja Satuan Kerja Perangkat Daerah (SKPD) di Kota

Bengkulu. Simpsium Nasional Akuntansi XIII, Purwokerto 
Ghozali, Imam. 2006. Analisis Multivariate dengan Menggunakan Program SPSS. Semarang: BPFE UNDIP.

Hay, Leon E., 1997. Accounting for Governmental And Non-profit Entities, 9th Ed., Boston : Richard D. Irwin Inc..

Hendriksen, Eldon S., 2005, Teori Akuntansi, Terjemahan oleh Marianus Sinaga, Edisi Kelima, Jakarta: Erlangga.

Latifah, Lyna dan Arifin Sabeni. 2007. Faktor Keperilakuan Organisasi Implementasi Sistem Akuntansi Keuangan Daerah. SNA X. UNDIP Semarang.

Mahmudi, 2010. Analisis laporan keuangan pemerintah daerah, edisi kedua. Yogyakarta: UPP STIM YKPN.

Mardiasmo.2002. Otonomi dan Manajemen Keuangan Daerah. Yogyakarta:ANDI.

Novi Andiani, 2012. Pengaruh Sistem Pengelolaan Keuangan Daerah Dan Implementasi Sistem Akuntansi Keuangan Daerah Terhadap Fungsi Pengawasan Keuangan Daerah (Studi Pada Dinas Pendapatan Pengelolaan Keuangan Dan Aset Daerah (Dppkad) Di Kabupaten Boyolali)

Nur Indriantoro dan Bambang Supomo. 2002. Metodologi Penelitian Bisnis. Yogyakarta: BPFE.

Rohman, Abdul. 2007. Pengaruh Peran Manajerial Pengelola Keuangan dan Fungsi Pemeriksaan Intern terhadap Kinerja Pemerintah Daerah (Survei pada Pemda Kota, Kabupaten di Provinsi Jawa Tengah). Jurnal MAKSI, Vol. 7, no. 2: 206-220. Agustus.

Sugiyono. 2006. Metode Penelitian Bisnis. Bandung: Alfabeta

Susmanto, Bintang. 2008. Pengawasan Intern pada Kementerian Koordinator Bidang Kesejahteraan Rakyat.

Suwardjono. 2005. Teori Akuntansi Perekayasaan Pelaporan Keuangan. Edisi Ketiga. Yogyakarta: BPFE

Tuasikal, Askam. 2009. Pengaruh Pengawasan, Pemahaman Sistem Akuntansi Keuangan dan Pengelolaan Keuangan Terhadap Kinerja Unit Satuan Kerja Pemerintah Daerah. Universitas Pattimura Ambon. Vol. 10, No. Juni. Hlm. 66-88.

Wilkinson, et al. 2000. Accounting information systems:Essential concepts and applications (4the,). NewYork:John Wiley and sons. Inc.

Winidyaningrum dan Rahmawati, 2010. Pengaruh Sumber Daya Manusia Dan Informasi Teknologi Pemanfaatan Kehandalan Dan Ketepatan Waktu Pelaporan Keuangan Pemerintah Daerah Dengan Variabel Intervening Pengendalian Internal Akuntansi. 